\title{
Interest Group Participation, Competition, and Conflict in the U.S. Supreme Court
}

\author{
Paul M. Collins, Jr. and Lisa A. Solowiej
}

In this article, we analyze how pluralistic, competitive, and conflictual interest group amicus curiae participation is in the U.S. Supreme Court. Examining participating organizations and briefs during the 1995 term, we address three inquiries. First, we scrutinize the types of organized interests who participate as amici curiae. We find that the Court is open to a wide array of interests and that particular types of groups do not dominate amicus activity. Second, we analyze the frequency with which amici file briefs on opposing sides of dispute. We reveal few strict patterns of competition, suggesting that Supreme Court cases are salient to a diverse spectrum of interest groups, many of which are not usually thought of as being in competition with one another. Third, we investigate how often and which amici directly cite one another for purposes of invalidating each other's argumentation. While amici have a great deal of opportunity for this form of direct conflict, it is surprisingly rare. Nonetheless, when amici engage in this express form of discord, they play a clear role in shaping the flow of information at the Court.

Paul M. Collins, Jr. is Assistant Professor of Political Science at the University of North Texas. He received his PhD from Binghamton University. His research focuses primarily on appellate court decision making, with a special interest in the role of pressure groups in the courts. He can be contacted at pmcollins@unt.edu.

Lisa A. Solowiej is a $\mathrm{PhD}$ Candidate in Political Science at Binghamton University and Lecturer in Political Science at the University of North Texas. Her research interests include legislative behavior and procedures, political parties, and interest groups. She can be contacted at lsolowiej@unt.edu.

The authors extend their thanks to Tom Brunell, Wendy Martinek, and the anonymous reviewers for their lucid comments and critiques of earlier versions of this article, and Joseph Kearney and Thomas Merrill for generously sharing their data with us. Collins thanks the National Science Foundation for its financial support under grant SES-0350416. Naturally, we assume all responsibility for errors in fact and/or judgment. A previous version of this article was awarded the 2003 CQ Press Award from the Law and Courts section of the American Political Science Association. 


\section{INTRODUCTION}

Interest groups pursue their goals in a variety of venues, including the courts. From testifying at judicial nomination hearings (e.g., Caldeira, Hojnacki, and Wright 2000) to case sponsorship (e.g., Wasby 1995), interest groups are an ever-present force in the judicial arena. ${ }^{1}$ Arguably, the primary judicial tool at the disposal of groups is the amicus curiae brief (Epstein 1991; Scheppele and Walker 1991, 162). In recent years, amici curiae have participated in over 80 percent of cases heard on the merits in the U.S. Supreme Court (Kearney and Merrill 2000; Wohl 1996). Far from its literal translation, however, these "friends of the court" are hardly neutral third parties. Instead, amicus participants act as advocates for the parties, urging the courts to rule in favor of one party over another (Krislov 1963). In this sense, organized interests are a meaningful part of the adversarial system that is American jurisprudence in which parties make their cases to judges advocating for divergent applications of the law. ${ }^{2}$

Scholars studying amicus participation in the Supreme Court have taken a variety of approaches. Most commonly they have focused on whether this method of participation influences litigation success (e.g., Collins 2004; Ivers and O'Connor 1987; Kearney and Merrill 2000; McGuire 1990, 1995; O'Connor and Epstein 1982; Puro 1971; Segal 1988; Songer and Sheehan 1993) or the content of the Court's opinions (e.g., Behuniak-Long 1991; Ennis 1984; Kearney and Merrill 2000; Kolbert 1989; O'Connor and Epstein 1983a; Samuels 2004; Spriggs and Wahlbeck 1997; Sungaila 1999). Here, we focus on what is perhaps the most underdeveloped aspect of the literature on amicus participation-determining how pluralistic, competitive, and conflictual amicus participation is in the Court (Bradley and Gardner 1985; Caldeira and Wright 1990; Kuersten and Jagemann 2000; O'Connor and Epstein 1983b). By pluralistic, we mean that, not only do organized interests represent various segments of society (e.g., corporations and unions), but also that these distinct groups have an opportunity to influence public policy. It is useful to distinguish pluralist perspectives of interest groups from elitist views of interest representation in which institutions and businesses dominate lobbying activity (e.g., Salisbury 1984; Schattschneider 1960). For pluralists, competition between diverse groups prevents one organized interest from

1. In addition to these methods of participation in the judiciary, groups may also pursue planned litigation campaigns (e.g., Wasby 1995), act as intervenors (e.g., Lowman 1992), and seek to influence the Court by authoring law review articles favorable to their causes (e.g., Epstein 1985).

2. We use the term "organized interests" in a very broad sense. Included are businesses, trade and labor organizations, public interest law firms, governments, unions, and the like (Caldeira and Wright 1990). As such, we adopt Schlozman and Tierney's $(1986,11)$ view that organized interests are a "variety of organizations that seek joint ends through political action." 
dominating the political arena, thus moderating public policy (e.g., Dahl 1961; Truman 1951). For elitists, the dominance of particular types of groups who represent moneyed interests - namely corporate and institutional organizations-reflects underlying biases in the political system (Schattschneider 1960). In this article, we add to our understanding of interest group participation by examining whether the interest group choir heard in the Supreme Court is more consistent with a pluralist or elitist viewpoint. ${ }^{3}$ In addition, by analyzing competition and conflict between the amici, we shed new light on how amici vie with one another in their attempts to influence the Court's policy outputs.

Investigating the pluralist or elitist nature of interest group involvement in the Court, as well as the levels of competition and conflict between the amici, is significant for a number of reasons. First, such an analysis speaks directly to the ability of interest groups to overcome intrinsic biases in the American political system. In particular, it has been noted that one of the primary reasons groups turn to the judicial arena is due to a lack of access to more traditional venues of influence, such as the legislative and executive branches (e.g., Cortner 1968; Vose 1955). Whereas admittance into the elected branches of government requires a great deal of political resources (e.g., money, professional lobbyists), no such barriers exist in the judicial branch; rather, the key resources required in the courts are legal (e.g., attorneys), and not political, in nature. For example, it is well established that, absent a geographic connection to a district, a prerequisite to gaining access to Congress is campaign donations (e.g., Berry 1997, 151; Wright 1989). Conversely, barriers to access in the judicial branch do not strictly involve monetary assets, but instead involve meeting standing requirements and the retention of counsel. While the aforementioned studies of group involvement in the courts provide intuitions that politically disadvantaged groups are able to utilize the courts as an outlet for social change, they focused on a small number of groups and cases. As such, a more systematic and large-scale analysis is required to determine the frequency with which membership-based organizations utilize the courts as a means to influence public policy.

Second, an understanding of who participates in the Court is important for assessing the competitive nature of Supreme Court litigation. In particular, Epstein (1985) posits that one of the primary reasons conservative interest groups turned to the courts in the 1960s was to provide a counterbalance to their opposition's perceived dominance in the judiciary. Witnessing the successes of amicus briefs filed by liberal groups, such as the American Civil

3. For the purposes of this article, all references to amicus participation refer to the Supreme Court's decisions on the merits. We focus on this because past research indicates that little competition among groups exists at the case selection stage (Caldeira and Wright 1988; Perry 1991). 
Liberties Union (ACLU) in Mapp v. Ohio (1961), ${ }^{4}$ conservative organizations established themselves to present the justices with alternative interpretations of the Constitution to counterbalance those arguments made by their liberal adversaries (O'Connor and Epstein 1989, 21). As a spokesperson for one such group, Americans for Effective Law Enforcement, put it, the group's purpose was "not to put the ACLU out of business (but) to make sure that the courts hear the law enforcement side of arguments." ${ }^{5}$ While it is often assumed that groups compete with one another by filing briefs on opposing sides of a dispute, little systematic attention has been paid to exploring this phenomenon, and virtually no research has examined the frequency with which different types of groups compete with one another. By investigating group competition and conflict in a systemized manner, we provide evidence as to whether groups actively counterbalance one another to prevent each other from dominating amicus curiae activity in the Court.

Finally, although we do not analyze the influence of amici on the Court's decision making, examining the nature of interest groups participating in the Supreme Court is important for a more complete comprehension of the relationship between amicus participation and judicial decision making. In particular, if the justices are only hearing from particular types of groups, this implies that the arguments presented to them are likely very homogenous. For example, if corporations dominate amicus activity in the Court, it is probable that the justices are rarely presented statistical evidence as that information is generally espoused by trade associations and public interest groups (Rustad and Koenig 1993). ${ }^{6}$ If, however, the justices are hearing from a multitude of voices in the Court, this increases the chances that each organized interest offers the Court novel argumentation that might otherwise be unavailable to it. Simply put, groups of the same organizational typology are likely to rely on similar presentation styles and authorities in their advocacy efforts. As such, a heterogeneous choir of interest group voices in the Court suggests that the justices receive a wide range of information that might aid them in creating efficacious law. This is a particularly important contribution, given the sometimes determinative influence groups have in the justices' decision making. Akin to the Mapp decision discussed above, researchers utilizing a variety of methodologies have provided robust evidence that interest group are successful in shaping the choices justices make (e.g.,

4. Importantly, Mapp began as a relatively routine dispute involving the possession of allegedly obscene materials. It was only at the suggestion of the ACLU that the Court extended the exclusionary rule to state prosecutions (Day 2001).

5. Quoted in Ivers and O'Connor (1987, 164).

6. For example, in BMW of North America v. Gore (1996), a case involving punitive damage awards, the Business Council of Alabama provided the Court with statistical data regarding punitive damage awards in that state, which were directly refuted in the brief of Alabama Trial Lawyers. 
Collins 2004, 2007; Kearney and Merrill 2000; Lynch 2004; Samuels 2004). Indeed, as Ennis $(1984,603)$ put it, amicus briefs are not just the icing on the cake; "they are often the cake itself." Accordingly, by analyzing organizations that compete for influence in the Court, much can be learned about the types of amici who have the potential to influence the Court's policy outputs, which in turn, sheds light on the choices justices make.

We begin our examination of organized interests in the Court by revisiting Caldeira and Wright's (1990) analysis to determine whether the picture they painted of pluralistic participation holds true for the 1995 term, despite the increase in amicus participation since their analysis of the 1982 term. In this section, we investigate which types of organized interests participate most often in the Supreme Court. While Caldeira and Wright provide compelling evidence that the Court is open to a diverse collection of groups, their analysis focuses on the 1982 term. By updating their analysis with data on the 1995 term, we seek to determine if any differences regarding the pluralistic nature of amicus participation have manifested themselves over time. ${ }^{7}$ Following this, we extend the work of Caldeira and Wright by exploring how often amici file briefs on opposite sides of a dispute for the purposes of attempting to influence the justices' decision making. We do so because interest group scholars have long recognized that the politics of organized interests may be best understood by the amount and type of competition that exists between opposing groups (e.g., Bentley 1908; Salisbury et al. 1987; Truman 1951). Finally, we analyze the frequency of conflict between groups by determining how often amici directly address their opponents' arguments in their briefs. Specifically, we examine the extent to which respondent amici address the arguments made by petitioner amici for purposes of invalidating or weakening their oppositions' arguments. ${ }^{8}$ An investigation into direct discord between the amici contributes to a more complete understanding of the pluralistic nature of organized interests in the Court since this stresses conflict among groups, and not simply their presence on either side of a case. Moreover, while groups who file briefs on opposite sides of a dispute may do so to simply "show the flag," that is, to remind the justices and their opposition that they are present in a case (Wasby 1995, 226), by directly addressing the arguments made by their opponents, amici become more fully engrained in the adversarial process, further contributing to the give and take that is Supreme Court adjudication. In addition, by engaging in this type of conflict, amici alter the information environment at the Court by drawing the justices' attention to points of law and fact in

7. While it would be ideal to measure participation and competition over several terms of the Court, the logistics of the data collection, as well as the time necessary to complete it, made an examination of a longer time frame unrealistic.

8. We examine the respondent amici because, under the Supreme Court rules, they are the only amici that have the opportunity to directly address arguments made by their opposition. 
their opponents' briefs. Thus, an analysis of conflict between the amici sheds light on the nature of the argumentation presented by the amici, contributing to our understanding of the insights organizations offer the justices with regard to legal and policy concerns.

This article proceeds as follows. First, we examine amicus participation during the 1995 term, highlighting the competition that exists among opposing amici. Next, we present our classification scheme and evaluate participating amici during this term. Following this, we analyze how often and which groups clash in the Court by filing briefs on opposing sides of a dispute. We then investigate the extent to which amici address their opponents' arguments in their briefs. Finally, we offer a discussion of the implications of this analysis for the study of interest group participation in judicial politics, as well as suggestions for future research in this area.

\section{AMICUS PARTICIPATION IN THE 1995 TERM}

\section{How Much?}

To answer the questions posed above, we examine all amicus participation during the 1995 Supreme Court term. Specifically, we obtained data from Kearney and Merrill (2000) that includes the number of briefs filed in each case during this term, as well as which litigant these amici supported (i.e., petitioner, respondent, or neither party). ${ }^{9}$ This enabled us to locate and examine each brief, without performing the somewhat sizable task of locating each case with amicus participation and counting the number of amicus briefs filed. Additionally, because we have no reason to think the 1995 term unusual (Jost 1996; Kearney and Merrill 2000), we can gain insight into current amicus participation by examining a term that generally reflects the Court's current docket and consisted of the same members as the final Rehnquist Court.

As has become the norm (Epstein 1991; Wohl 1996), there was a great deal of amicus participation during the 1995 term. Of the four hundred amicus briefs filed, at least one was filed in over 75 percent of cases disposed of by

9. Because Kearney and Merrill (2000, 836-43) used the United States Reports, which only lists the position of the brief if it was included in the "conclusion" section of the brief and not all amicus briefs contain this information in the conclusion section, almost 20 percent were originally identified as being filed for neither party $(\mathrm{N}=78)$. Since this struck us as a larger percentage of amicus briefs being filed for neither party than we believed comported with reality (see Gibson 1997; Kearney and Merrill 2000), we examined the content of these briefs and assigned all but two to either the petitioner or the respondent. The two briefs filed on behalf of neither party were filed for "Two Product Liability Law Professors" in Medtronic v. Lohr (1996), and the American Intellectual Property Law Association in Lotus Development v. Borland International (1996). 
TABLE 1.

Amicus Curiae Participation in the 1995 Supreme Court Term

\begin{tabular}{lcc}
\hline & All Cases $^{\mathrm{a}}$ & Orally Argued Cases $^{\mathrm{a}}$ \\
\hline Cases Decided by the Court & 91 & 76 \\
With Amicus Participation & $70(76.9 \%)$ & $70(92.1 \%)$ \\
With Petitioner Amici & $58(63.7 \%)$ & $58(76.3 \%)$ \\
With Respondent Amici & $56(61.5 \%)$ & $56(73.7 \%)$ \\
With Petitioner and Respondent Amici & $44(48.4 \%)$ & $44(57.9 \%)$ \\
With Petitioner, but not Respondent Amici & $14(15.4 \%)$ & $14(18.4 \%)$ \\
With Respondent, but not Petitioner Amici & $12(13.2 \%)$ & $12(15.8 \%)$ \\
Total Number of Amicus Briefs Filed & 400 & 400 \\
Mean Number of Amicus Briefs per Case & 4.4 & 5.3 \\
\end{tabular}

a Using case citation as the unit of analysis.

Note: Two briefs were filed for "neither party."

the Court and, of the cases disposed of with oral argument, over 90 percent had at least one amicus brief. We report these figures in Table 1; column one reports all cases disposed of by the Court, and column two reports only those cases disposed of with oral argument. As Table 1 demonstrates, all amicus participation occurred in orally argued cases. This confirms the conventional wisdom that the Court does not ordinarily decide an issue of enough importance to attract the attention of organized interests without hearing oral argument (e.g., Kearney and Merrill 2000, 825). Given this, it appears that interest groups, similar to the public, view the orally argued cases as the Court's real business for a particular term.

Table 1 also reveals that there was a great deal of competition among amici in the Court during the 1995 term. Of the cases with amicus participation $(\mathrm{N}=70), 63$ percent had at least one brief filed in support of the petitioner and at least one brief filed in support of the respondent. While this is suggestive of a great deal of competition among organizational amici, it does not speak to what types of groups filed these briefs nor whether certain types of groups dominated amicus activity in terms of the frequency of participation. We now focus our attention to investigating these questions.

\section{Who Participates?}

Social scientists and legal scholars have long utilized classification schemes to describe and analyze interest group activity (e.g., Truman 1951; Salisbury et al. 1987; Schlozman and Tierney 1986; Walker 1991), frequently to reduce the complexities of interest group involvement in the courts. While scholars have taken numerous approaches, from dichotomizing groups as 
TABLE 2.

Organizational Classification of Amici Curiae

\begin{tabular}{ll}
\hline Type of Amicus & Examples \\
\hline $\begin{array}{l}\text { Individual } \\
\text { Corporation }\end{array}$ & Academics, Legislators, Physicians, Scientists \\
$\begin{array}{l}\text { Government } \\
\text { U.S. }\end{array}$ & Dollar Bank, Hearst Corporation, Trinity Ventures \\
State & Comptroller of Currency, Solicitor General \\
Local & City of Aspen, County of Alameda \\
$\begin{array}{l}\text { Public Advocacy } \\
\text { Public Interest }\end{array}$ & American Civil Liberties Union, Older Women's League \\
Law Firm & Criminal Justice Legal Foundation, Trial Lawyers for Public Justice \\
Trade Association & American Bar Association, American Psychological Association \\
Union & Major League Baseball Players Association, United Steelworkers \\
& of America \\
Peak Association & AFL-CIO, Chamber of Commerce \\
Other & Committee for Party Renewal, San Manuel Band of Mission \\
& Indians \\
\end{tabular}

being liberal or conservative (e.g., O'Connor and Epstein 1983b) or upperdog and underdog (e.g., Bradley and Gardner 1985), we adopt the classifications of Caldeira and Wright (1990; see also Epstein 1994). That is, we classified groups on the basis of their basic unit of membership by distinguishing between institutional groups and membership groups, between citizen groups and trade associations, and between peak associations and governmental entities. This classification offers us two advantages. First, by adopting the general scheme of Caldeira and Wright (1990), we are able to compare their findings on the 1982 term of the Court to a more recent term of the Court to determine if interest groups are as equally well represented during the 1995 term or if particular types of groups dominated amicus activity during this term. Second, it enables us to generalize more broadly about interest group participation in the Court from our analysis of a single term. Because the Court's social and economic agendas change regularly, classifying groups as liberal or conservative (e.g., O'Connor and Epstein 1983b), while useful, may be unduly sensitive to particular years and particular courts.

Our classification of amici is reported in Table 2. Note that we have made two minor changes to the typology of Caldeira and Wright. First, since local government participation is relatively rare, and the distinction, in our view, is not of extreme import, we combined counties, municipalities, and other forms of local governments into one category of all local governments. Second, our public advocacy category includes organizations classified by Caldeira and Wright's as charitable and community organizations, as well as citizen/public interest/advocacy groups. We combined these categories of groups for three reasons. First, we believe that the distinction between 
charitable or community organizations and citizen/public interest/advocacy organizations is so arbitrary that it borders on being unreliable and invalid. ${ }^{10}$ For example, Caldeira and Wright categorize the March of Dimes as a charitable organization and Mothers Against Drunk Driving (MADD) and the National Association for the Advancement of Colored People (NAACP) as citizen/public interest/advocacy groups. However, since all of these groups pursue policies they view as being central to the public interest and are tax-exempt 501(c)(3) charitable organizations, we fail to make this distinction. Second, while the Internal Revenue Service (IRS) does set strict limitations on the amount of political advocacy that can be conducted by 501(c)(3) charitable organizations, these restrictions do not apply to lobbying the courts. As such, in terms of accessing the courts, charitable organizations face no unique barriers (Basinger 2004). Finally, if we created distinct categories on the basis of an organization's tax status, such as separating 501(c)(3) organizations from 501(c)(4) organizations, this would obfuscate our ability to compare our results to those of Caldeira and Wright as we would not be able to confidently state that the groups included in our public advocacy category match those organizations Caldeira and Wright categorize as public advocacy groups. Further, if we utilized such a distinction, this would virtually eliminate our public interest law firm typology; of the nearly forty distinct public interest law firms in the data only the National Veterans Legal Services Program is not a 501(c)(3) charity.

While the classification of many of the categories of amici is self-evident (i.e., individuals, corporations, governments, and unions), a discussion of the remaining five categories is useful to eliminate any ambiguity that might exist with respect to how organized interests were determined to conform to a particular category. A group is classified as a public advocacy organization if its membership is made up of individuals-regardless of their occupational status - and the primary goal of the group is political, and not economic, in nature. For example, the American Association of Retired Persons (AARP) is classified as a public advocacy organization as it defines itself as

a non-profit membership organization of approximately thirty-three million people aged fifty and older. In representing the interests of its members, AARP seeks to: (1) enhance the quality of life for older people; (2) advance the role and place of older people in society; (3) sponsor research on the physical, psychological, social, economic and other aspects of aging; and (4) support public policies to protect the rights of older people in a broad range of marketplace transactions. ${ }^{11}$

10. We use these terms with very specific meanings in mind. By reliable we mean that, in applying the same data collection procedures in the same way, this will always produce the same result. By valid, we mean that we are measuring what we think we are measuring (e.g., Epstein and King 2002, 83-97; King, Keohane, and Verba 1994, 25-26).

11. See amicus curiae brief of AARP, Doctor's Associates v. Casarotto (1996). 


\section{LAW \& SOCIAL INQUIRY}

Because participation in public advocacy organizations is open to individuals, such groups are classified as membership organizations.

An organization is classified as a public interest law firm if it is a nonprofit legal entity that either provides attorneys to represent individuals in a manner consistent with the group's jurisprudential philosophy or initiates lawsuits itself on behalf of the interests of its members. Thus, the primary difference between a public advocacy organization and a public interest law firm stems from the fact that public interest law firms focus on providing individuals and other entities with legal counsel. In point of fact, it was almost effortless to classify such groups as they almost uniformly identified themselves as nonprofit law firms, public interest law firms, or some combination of the two. For example, the New England Legal Foundation (NELF) identifies itself as a "a non-profit, public interest law firm." 12 As mentioned above, with only one exception, every public interest law firm that participated in the 1995 term is classified by the IRS as a 501(c)(3) charity and accepts donations from individuals. While public interest law firms differ as to how they classify such donors-some refer to donors as members (e.g., National Legal Aid and Defender Association), others refer to donors as contributors (e.g., Institute for Justice), and, for a few, the term "member" is used contingent upon the size of the donation (e.g., Bazelon Center for Mental Health Law) - the unifying characteristic is that such organizations accept donations (often providing selective incentives in exchange for those donations), regardless of an individual's occupational status. Thus, it is germane to classify public interest law firms as membership organizations. ${ }^{13}$

An interest group is classified as a trade association if the distinguishing characteristic of the group is that membership is based on occupation in a given profession. ${ }^{14}$ Thus, trade associations differ from public advocacy groups because there are no occupational barriers to joining public advocacy organizations, while such barriers do exist with regard to membership in a trade association. In addition, these organizations differ from public advocacy groups because they tend to seek economic, as well as political, benefits for their members. For example, the Maritime Law Association (MLA) identifies itself as

a nationwide bar association founded in 1899, with a membership of about 3600 attorneys, law professors and others interested in maritime law. It is affiliated with the American Bar Association and is represented

12. See amicus curiae brief of NELF, Loving $v$. United States (1996).

13. Of course, it is important to note that public interest law firms also receive contributions from institutions, including charitable foundations, but this in no way distinguishes them from other membership-based groups, who also heavily rely on individual and institutional patronage for organizational maintenance (Walker 1991).

14. Our trade association category is synonymous with Caldeira and Wright's (1990) category of "business, trade, and professional organizations." 
in that Association's House of Delegates. Its attorney members, most of whom emphasize their practice in admiralty law, represent all maritime interests_-shipowners, charterers, cargo interests, port authorities, seamen, longshoremen, passengers, underwriters and other maritime claimants and defendants. ${ }^{15}$

Classifying trade associations as membership or institutional amici is somewhat ambiguous (Salisbury 1984, 70). On the one hand, such groups are generally managed organizations that pursue economic benefits for their members; as such, several have classified trade associations as institutional groups (e.g., Caldeira and Wright 1990; Salisbury 1984; Schlozman 1984). On the other hand, because membership in trade associations is not compulsory for individuals in a particular occupation, and because the leadership of such groups must consider — at least in part — the interests of its members in making lobbying decisions, it is also appropriate to classify trade associations as membership organizations. In order to promote comparability with Caldeira and Wright's (1990) findings, we consider trade associations to be institutional amici; however, we also discuss whether classifying trade associations as membership groups might alter the findings presented here.

Interest groups are classified as peak associations if they are organizations of organizations. In other words, a peak association is an interest group that represents the interests of other institutions, such as labor unions and businesses. Thus, the defining feature of a peak association is that it does not have members in the ordinary sense; instead, its membership is made up of institutions. For example, the American Network of Community Options and Resources (ANCOR)

represents more than 660 agencies nationwide that together support more than 50,000 people with mental retardation and other disabilities. Most of the members operate community residences and support people in their own homes. About 85 percent of ANCOR members are nonprofit agencies. The remainder are proprietary agencies or unincorporated family care homes. ${ }^{16}$

As the membership of peak associations consists entirely of institutional amici, we classify peak associations as institutional organizations.

Finally, interest groups who do not conform to any of the aforementioned categories are classified as "other" amici. These include the San Manuel Band of Mission Indians, the U.S. Navy Appellate Defense Division, as well as ad hoc organizations such as the Plaintiffs' Committee In re Air Crash Disaster at Lockerbie, Scotland. Due to the diversity of such organizations,

15. See amicus curiae brief of MLA, Exxon v. Sofec (1996).

16. See amicus curiae brief of American Association on Mental Retardation et al., Cooper v. Oklahoma (1996). 
we do not classify these amici as institutional or membership groups; instead, we exclude them from our discussion of the pluralist or elitist nature of interest group involvement in the Court. It is important to note that some may take issue with our coding decisions. For example, one might categorize the ACLU as a public interest law firm because it provides counsel to its members. Conversely, one might classify Trial Lawyers for Public Justice (TLPJ) as a public advocacy organization because it engages in public education campaigns and disseminates information it views as vital to the public interest. However, because of the broad scope of the ACLU and the fact that TLPJ primarily engages itself in litigation campaigns, we believe our classification scheme is most fitting.

Our analysis of amicus participation is based on data we collected on all cases, decided on the merits, during the 1995 Supreme Court term. Initially, we identified each case with amicus participation and then located each amicus brief using LexisNexis. ${ }^{17}$ We then applied our coding scheme to classify each amicus participant on the brief using the information found in the section of the brief entitled "Interests of Amicus Curiae."18 All amici were classified, with no particular importance given to those amici who appear first on the brief because amici may list themselves alphabetically or randomly on the briefs (Behuniak-Long 1991; Gibson 1997).

Table 3 reports our findings. The first column, number of cases, indicates the number of cases in which at least one of the amicus types appeared on a brief. This allows us to examine the number of cases in which each type of amicus participated. ${ }^{19}$ As Table 3 reveals, the most frequent amicus participants were trade associations, who participated in almost 70 percent of amicus cases (where at least one amicus brief was filed), followed by public advocacy organizations, who participated in almost 60 percent of amicus cases. Unions and local governments were the least frequent amicus filers during the 1995 term.

The second column, number of briefs, indicates the number of briefs in which at least one of the amicus types appeared on a brief. Of the four hundred amicus briefs filed, at least one trade association appeared on 34 percent of the briefs; at least one public advocacy organization appeared on 18 percent of the briefs. This should not be surprising considering that these two types of organizations participated in the highest number of amicus cases, as reported in column one. The third column indicates the number of times each of the categories of amici appeared on a brief. Contrary to our findings

17. For the 2 percent of briefs we could not find on Lexis we used Westlaw.

18. Under Supreme Court Rule 37 all amicus briefs are required to contain this section.

19. Note that inclusion in this category is not mutually exclusive because, in the majority of the seventy cases in which at least one amicus brief was filed, there was participation by more than one type of group. For this reason the entries in column one do not add to seventy, which is the total number of cases with at least one amicus brief filed. 
TABLE 3.

Amicus Curiae Participation by Type of Amicus Curiae

\begin{tabular}{lccccc}
\hline Type of Amicus & $\begin{array}{c}\text { Number of } \\
\text { Cases }\end{array}$ & $\begin{array}{c}\text { Number of } \\
\text { Briefs }\end{array}$ & $\begin{array}{c}\text { Number of } \\
\text { Amici }\end{array}$ & $\begin{array}{c}\text { Amici per } \\
\text { Case }\end{array}$ & $\begin{array}{c}\text { Amici per } \\
\text { Brief }\end{array}$ \\
\hline Individual & $20(28.6)$ & $34(8.5)$ & $376(22.3)$ & 18.8 & 11.1 \\
Corporation & $16(22.9)$ & $49(12.3)$ & $117(6.9)$ & 7.3 & 2.4 \\
Government & & & & & \\
$\quad$ U.S. & $25(35.7)$ & $25(6.3)$ & $29(1.7)$ & 1.2 & 1.2 \\
$\quad$ State & $23(32.9)$ & $31(7.8)$ & $349(20.7)$ & 15.2 & 11.3 \\
$\quad$ Local & $7(10.0)$ & $10(2.5)$ & $55(3.3)$ & 7.9 & 5.5 \\
Public Advocacy & $40(57.1)$ & $72(18.0)$ & $209(12.4)$ & 5.2 & 2.9 \\
Public Interest Law Firm & $31(44.3)$ & $47(11.8)$ & $71(4.2)$ & 2.3 & 1.5 \\
Trade Association & $48(68.6)$ & $136(34.0)$ & $293(17.4)$ & 6.1 & 2.2 \\
Union & $7(10.0)$ & $11(2.8)$ & $31(1.8)$ & 4.4 & 2.8 \\
Peak Association & $27(38.6)$ & $45(11.3)$ & $85(5.0)$ & 3.1 & 1.9 \\
Other & $8(11.4)$ & $18(4.5)$ & $71(4.2)$ & 8.9 & 3.9 \\
& 70 & 400 & 1,686 & $24.1^{\mathrm{a}}$ & $4.2^{\mathrm{a}}$ \\
All Amici & 70 & & & & \\
\hline
\end{tabular}

Numbers in parentheses indicate column percentages. These were derived by dividing the total number of times each type of amicus appeared on a brief by the total number of cases with amicus participation (column one), the total number of briefs filed (column two), or the total number of amici participating (column three). ${ }^{a}$ Indicates overall average.

regarding the number of briefs filed, compared to all other amici, state governments account for the largest proportion of organized interest participation. These findings support the contention that Supreme Court adjudication is of particular interest to the states (Kearney and Sheehan 1992; Morris 1987). In general, Caldeira and Wright's findings hold true for our analysis, with only two exceptions. First, while Caldeira and Wright found that individuals accounted for only 6 percent of the amici during the 1982 term, they account for over 22 percent in the 1995 term. ${ }^{20}$ In addition, we find that public advocacy groups constitute only 12 percent of the amici, compared to almost 20 percent during the 1982 term.

Although there are no strict guidelines for establishing whether interest group participation is more consistent with a pluralist or elitist account of representation, Salisbury's (1984) and Schlozman's (1984) seminal studies of organized interests can be utilized for means of comparison. Salisbury (1984, 74) found that membership-based groups constituted only 18 percent of the interest groups participating in agricultural policy and used that figure to

20. This apparent increase could be explained by the tendency of individuals to cosign amicus curiae briefs. For example, in Lotus Development v. Borland International (1996), 81 individuals filed an amicus curiae brief together, simply listed as "Computer Scientists." This one brief contributed almost 20 percent of the 376 individual amici participants in column three. 
establish the dominance of institutions in that policy arena (i.e., an elitist view of representation). If we consider the number of amici for comparison (column three), it is clear that organized participation in the Court is most consistent with a pluralist account of representation. Institutions (corporations, governments, trade associations, and peak associations) cumulatively make up 55 percent of amici in the Court, with membership-based organizations and individuals accounting for more than 40 percent. If we reclassify trade associations as membership-based groups, institutions make up only 38 percent of amici in the Court, with the vast majority of interests constituting membership-based organizations and individuals. When we examine the number of briefs filed (column two), as opposed to the number of amici, a similar picture emerges. Institutional amici appeared on 74 percent of the briefs, while membership groups and individuals appeared on 41 percent of the briefs. ${ }^{21}$ Although not providing as compelling support for a pluralist choir as our analysis of the number of amici, these results, nonetheless, indicate that membership groups are a strong presence in the Court. Further, if we exclude trade associations from consideration due to their ambiguous nature, institutional and membership amici appear on amicus briefs in almost identical numbers. Thus, whether one examines the number of amici or the number of briefs filed, and regardless of how one treats trade associations, it is clear that membership-based groups play an important part in Supreme Court litigation.

Schlozman (1984) examined interest group representation in Washington and revealed that 70 percent of all organizations with a presence in Washington represent business interests. In interpreting this data, Schlozman (1011) concluded that "the pressure system is heavily weighted in favor of business organizations," thus providing evidence for elitist accounts of pressure group activity. Looking first to column three, business interests (corporations and trade associations), make up only 24 percent of amici participating in the 1995 term, with the overwhelming majority of organizations consisting of governmental interests, public advocacy groups, public interest law firms, unions, and peak associations. Turning to column two, business interests appeared on 46 percent of amicus briefs, with the other organizational types appearing on more than 60 percent of the briefs. Given these findings, we are able to conclude that the Supreme Court is not wholly dominated by institutions or business interests, but instead is open to a broad array of pressure groups.

The fourth and fifth columns of Table 3 provide information on the coalitional activity of organized interests and report the number of amici appearing in each case and on each brief, respectively, for each category of amicus. Overall, the Court sees an average of twenty-four amici participating

21. Similar to column one, inclusion on a brief reported in column two is not mutually exclusive because, on the majority of the four hundred briefs, there was participation by more than one type of group. For this reason the percentages in column two do not sum to one hundred. 
in cases in which at least one amicus brief was filed. Moreover, when there is participation by one organizational type in a case, these results indicate amici of the same type join in this participation. This is particularly true for individuals and state governments, who appear, on average, over fifteen times per amicus case.

Similar to Caldeira and Wright (1990), we find a general absence of coalitional activity for organizations of the same type. ${ }^{22}$ However, we do find that states and individuals frequently join the same briefs. We find an average of eleven amici for both individuals and states, which are much higher than the averages of four and six, respectively, found by Caldeira and Wright. Such findings with regard to individuals and states should not be surprising. Because amicus participation is a relatively expensive method of interaction with the judiciary (Caldeira and Wright 1988), it is likely that individuals cosign amicus briefs to share the expense of filing amicus briefs with similarly interested individuals. In addition to their shared interests, particularly with regard to federalism issues, states likely participate in this form of coalitional activity because they have in place a unique infrastructure for doing so. In particular, the National Association of Attorneys General has greatly increased its role with regard to effective interaction between the states since the 1982 term by orchestrating a communications network that informs state officials about amicus activity in other states (Morris 1987, 300).

\section{COMPETITION IN THE 1995 TERM}

We next seek to understand the amount of competition among different types of organizations appearing as amici. To do this, we adopt our measure of competition from Caldeira and Wright (1990) and analyze the number of times that organizations filed briefs on opposing sides of a dispute. Despite the fact that Caldeira and Wright only examined competition among organizations of the same type, they maintained that there was substantially more competition between groups of different types than between amici of the same type (802). Thus, while their analysis only made it possible to understand how often a certain group filed on the opposing side of that same group type, we seek to take the analysis further by looking at competition among different types of amici.

The results of our measure of group competition are shown in Table 4. Each type of organization is listed across the top of the table, while their

22. It is important to note that the dearth of coalitional activity for organizations of the same type may stem from the fact that organizations of the same type may coordinate the content of amicus briefs, without actually appearing on the same brief (Caldeira and Wright 1990, 800; Kolbert 1989). 
TABLE 4.

Competition Among Amici Curiae of a Given Type

\begin{tabular}{|c|c|c|c|c|c|c|}
\hline Amicus of Interest & Individual & Corporation & U.S. & State & Local & $\begin{array}{c}\text { Public } \\
\text { Advocacy }\end{array}$ \\
\hline \multicolumn{7}{|l|}{ Opponent Amicus } \\
\hline Individual & $4.1 \%(2)$ & $9.8 \%(4)$ & $0.0 \%(0)$ & $6.7 \%(5)$ & $12.5 \%(2)$ & $9.8 \%(11)$ \\
\hline Corporation & $8.2(4)$ & $7.3(3)$ & $10.0(4)$ & $4.0(3)$ & $0.0(0)$ & $5.4(6)$ \\
\hline U.S. & $0.0(0)$ & $9.8(4)$ & $0.0(0)$ & $9.3(7)$ & $6.3(1)$ & $4.5(5)$ \\
\hline State & $10.2(5)$ & $7.3(3)$ & $17.5(7)$ & $8.0(6)$ & $12.5(2)$ & $13.4(15)$ \\
\hline Local & $4.1(2)$ & $0.0(0)$ & $2.5(1)$ & $2.7(2)$ & $0.0(0)$ & $2.7(3)$ \\
\hline Public Advocacy & $22.4(11)$ & $14.6(6)$ & $12.5(5)$ & $20.0(15)$ & $18.8(3)$ & $8.9(10)$ \\
\hline Public Interest Law Firm & $20.4(10)$ & $7.3(3)$ & $15.0(6)$ & $12.0(9)$ & $18.8(3)$ & $18.8(21)$ \\
\hline Trade Association & $12.2(6)$ & $26.8(11)$ & $20.0(8)$ & $20.0(15)$ & $18.8(3)$ & $18.8(21)$ \\
\hline Union & $0.0(0)$ & $2.4(1)$ & $7.5(3)$ & $0.0(0)$ & $0.0(0)$ & $0.9(1)$ \\
\hline Peak Association & $10.2(5)$ & $9.8(4)$ & $15.0(6)$ & $9.3(7)$ & $6.3(1)$ & $11.6(13)$ \\
\hline Other & $8.2(4)$ & $4.9(2)$ & $0.0(0)$ & $8.0(6)$ & $6.3(1)$ & $5.4(6)$ \\
\hline Column Total & $100.0(49)$ & $100.0(41)$ & $100.0(40)$ & $100.0(75)$ & $100.3(16)$ & $100.2(112)$ \\
\hline
\end{tabular}




\begin{tabular}{lcrrr}
\hline Amicus of Interest & $\begin{array}{c}\text { Public Interest } \\
\text { Law Firm }\end{array}$ & $\begin{array}{c}\text { Trade } \\
\text { Association }\end{array}$ & Union & $\begin{array}{c}\text { Peak } \\
\text { Association }\end{array}$ \\
\hline Opponent Amicus & & & & \\
Other
\end{tabular}

Entries in table are column percentages. These percentages are derived from dividing the number of cases in which the amicus of interest appeared on a brief opposing the opponent amicus by the column total. These percentages may not necessarily sum to one hundred due to rounding. Numbers in parentheses indicate number of cases in which the amicus of interest appeared on a brief and an opponent amicus appeared on a brief advocating the opposite position of the amicus of interest (i.e., the amicus of interest appeared on a brief filed in support of the petitioner and the opponent amicus appeared on a brief filed in support of the respondent or vice versa). Column totals indicate the total number of cases in which the amicus of interest appeared on a brief advocating the opposing position of any one of the opponent amici. See text for further details. 
opponent amici are listed in the left-hand column. ${ }^{23}$ The first entry in the column indicates the percentage of times the amicus of interest, in this specific case individuals, filed an amicus brief, and an opponent amicus, in this case other individuals, filed a brief on the opposing side relative to the forty-nine briefs filed by individuals against all amici. Thus, this figure reveals that, of the forty-nine amicus briefs filed by individuals against the amici, individuals appeared on opposing sides of a dispute 4 percent of the time. The number in parentheses (2) denotes the number of cases that this percentage is based on, while the column total (49) indicates the total number of cases in which the amicus of interest appeared advocating the opposing position of the opponent amici. The second entry of 8 percent indicates that individuals appeared on a brief advocating the opposing position of a corporation in four of the forty-nine briefs they filed.

It is difficult to decipher any rigid patterns of competition from our findings. Thus, we might conclude that even a single Supreme Court case is salient to a diverse cross-section of groups who we would not typically think of as being in competition with each other and may not be outside of the Court. The campaign finance case of Colorado Republican Federal Campaign Committee v. FEC (1996) provides an excellent example of this. In this case, amici supporting the petitioner included the Committee for Party Renewal (a group of political scientists committed to strengthening political parties in the United States), the ACLU, several U.S. senators and representatives, the National Right to Life Committee, and the Republican National Committee. Amici for the respondent included six states, Common Cause, Public Citizen, and the Brennan Center for Justice at New York University School of Law. This broad array of organized interests clearly suggests that these groups believe the Court's decision will have a genuine impact on their seemingly disparate goals. Given this, it appears the Court is not only open to a wide array of pressure groups, but this diverse spectrum of groups often competes with each other in pursuit of their policy goals.

Although our results indicate few strict patterns, several observations can, nonetheless, be made. First, note that for all types of amici, when the amicus of interest is the same type as the opponent amicus, the levels of competition

23. In the data from which Table 4 is derived, a case in which each category of amici participated can theoretically appear eleven times (once for each category of opposition amici). Conversely, in Table 3, each case is counted only once. For example, in BMW v. Gore (1996), an amicus brief was filed by Richard L. Blatt, Robert W. Hammesfahr, and Lori S. Nugent (coded as individuals). This case is counted three times in Table 4 (with respect to the Blatt et al. brief): once tied to the brief of Legal Historians (individuals); once tied to the brief of Trial Lawyers for Public Justice (public interest law firm); and once tied to the following trade associations: the National Association of Securities and Commercial Law Attorneys, the Association of Trial Lawyers of America, and the Alabama Trial Lawyers Association, who each filed a separate amicus brief on the opposing side of the dispute. The purpose of counting cases more than once is to establish the frequency with which each category of amicus was in competition with another category of amicus. 
are among the lowest. This finding supports Caldeira and Wright's (1990) claim that competition is more frequent between amici of different types, as well as Salisbury et al.'s (1987) finding that organizations tend to ally with organizations of the same type. Second, in terms of the number of cases, the highest levels of competition among organized interests (i.e., excluding individuals) appear between public advocacy organizations and public interest law firms, and between trade associations and public advocacy organizations. ${ }^{24}$ Such findings should not be surprising; these group types perhaps best represent the diverse ideological spectrum of pressure groups vying for influence in American government. For example, in Shaw v. Hunt (1996), the Court considered the constitutionality of a North Carolina redistricting plan in which race was purported to be the predominant factor in defining a district's boundaries. The liberal ACLU (joined by the Lawyers' Committee for Civil Rights Under Law) filed a brief in support of the redistricting plan, while the conservative Pacific Legal Foundation argued that the plan was unconstitutional, as it violated the spirit of Brown v. Board of Education (1954). ${ }^{25}$ Similarly, in Whren v. United States (1996), the Court adjudicated whether drug evidence seized by plainclothes officers in an asserted routine traffic stop could be introduced at trial. The liberal ACLU, along with the National Association of Criminal Defense Lawyers, argued that the evidence should be suppressed, while the conservative Criminal Justice Legal Foundation, along with fourteen states and the California District Attorney's Association, argued that there was sufficient probable cause to include the evidence at trial.

In addition, these results reveal that states compete with the federal government frequently; of the forty briefs filed by the federal government, almost 20 percent of the time the federal government squared off against a state. For example, in Lewis v. Casey (1996), the Court considered the extent to which state prison officials must provide inmates access to legal research facilities, such as law libraries. In this case, thirty-three states joined a single brief in arguing that previous Court decisions establish the need to provide only limited access, while the U.S. Solicitor General argued for a much more expansive interpretation of the access requirement. ${ }^{26}$ In light of the salience

24. While unions and trade associations appear to compete with each other with great frequency on the basis of the percentages reported in the union column, it is important to note that the small number of observations from which these percentages are derived make any conclusions suggestive at best.

25. In addition, briefs in Shaw (1996) were filed in support of the redistricting plan by the Congressional Black Caucus, the North Carolina Legislative Black Caucus, and the U.S. Solicitor General.

26. In addition, separate amicus briefs joining the states' position were filed by the Criminal Justice Legal Foundation, the Conference of State Legislatures et al., and the Washington Legal Foundation et al. The Solicitor General's position was also briefed by the Legal Aid Bureau, the Mexican American Legal Defense and Education Fund et al., North Carolina Prisoner Legal Services, Prison Legal Services of Michigan, and a group of prisoners from northern California who were litigants in similar class-action lawsuits. 


\section{LAW \& SOCIAL INQUIRY}

and growing number of federalism issues before the Court, it is likely that this trend will continue into the Roberts Court. ${ }^{27}$

\section{CONFLICT IN THE 1995 TERM}

Our measure of conflict stresses discord in addition to competition. Here, we examine how often and which amici cite their opposition for the purposes of countering their arguments, as well as the frequency with which the respondent party engages in this type of conflict. Examining this type of direct dissention between the amici (and respondent party) is important for three reasons. First, by engaging in this type of conflict, amicus participants become more fully engrained in the adversarial dispute resolution process that is a key feature of American law. While traditional notions of conflict in the Court stress contention between the parties to litigation, amici also have the opportunity to engage themselves in the clash over the Court's policy outputs. Thus, just as pluralist notions of interest group participation in the polity suggest that group competition can moderate public policy, so too can interest group conflict in the judiciary. In addition, direct citations to opponent briefs are a valid indicator of group conflict because such citations indicate that the amici and respondents took the time to read and subsequently address their opponents' arguments. ${ }^{28}$ Second, our measure of conflict is useful because such citations in briefs are likely to draw the attention of the justices. Since the Court seldom sees only one brief filed in a case, directly citing one's opponent might prompt the justices to give particularly singular attention to the opponent's arguments, compelling them to more closely scrutinize the validity of these arguments. Accordingly, this measure might prove useful in future studies to help explain the Court's adoption of arguments made

27. Federalism cases constituted 4.1 percent of the Burger Court's docket, compared to 6.2 percent of the Rehnquist Court's docket (Spaeth 2004).

28. The alternative would be to determine whether amici addressed arguments in their oppositions' briefs without direct citations to said briefs. We argue that simply presenting an alternative to the arguments made by a group's opponents does not necessarily denote that the amicus read their opponents' briefs. An example can be found in Felker v. Turpin (1996), when the Court ordered all party and amicus briefs due no later than 2 p.m. on Friday, May 17, 1996. Thus, none of the amici had the opportunity to read their opponents' briefs prior to the submission date. While using our measure of direct citation would reveal no conflict in the case, evidence looking at contrary arguments would reveal conflict as all amici, save one, spoke to divergent applications of Ex Parte McCardle (1868) in the case. Though this case involves interest groups on opposing sides of the case making arguments that would appear to conflict with one another, we do not believe that these contrary legal arguments are indicative of any purposeful conflict between the amici. In addition, due to the practical limitations of such an approach (which would require coding and comparing every argument made in every amicus brief) and the possible reliability concerns stemming from such an approach, this measure would likely result in essentially total evidence of conflict between amici. 
by amici in its opinions. ${ }^{29}$ Finally, and most importantly, when this type of conflict occurs, it is a clear indication that amici alter the informational environment at the Court. Consider, for example, a case in which there is no amicus participation. In such a case, the plenary conflict is between the petitioner and the respondent, and this is reflected in those parties' briefs. However, when amici become involved in a dispute, they expand the scope of the conflict (Schattschneider 1960). By filing briefs in support of the petitioner, the result is that amici often compel the respondent amici and the respondent party to address their arguments for purposes of invalidating them. Insofar as amici alter the informational environment at the Court, this measure of conflict provides concrete insight into how amicus briefs present the Court with information that would otherwise be unavailable to it. Simply put, when respondent amici and the respondent party directly reference petitioner amicus briefs, this provides compelling evidence that amici are an important part of the adversarial process by shaping the information contained in their opposition's briefs (both party and amici), which may, in turn, influence the choices justices make.

To determine the extent of conflict, we collected data on all amicus briefs filed in the 1995 Supreme Court term in which there was at least one petitioner amicus brief filed. This is a necessary condition for our measure of conflict because, absent a petitioner amicus brief, no direct citation to an amicus brief can occur by respondent amici. ${ }^{30}$ Determining citations in amicus briefs proved to be no easy task. We base our approach on Kearney and Merrill's (2000) analysis of citations to amicus briefs in Supreme Court opinions. These authors find that "the Court is generally consistent in identifying any amicus to which it refers" (843). Adopting this logic, we first selected a random sample of ten respondent amicus briefs and read each brief to determine the consistent language used by Supreme Court attorneys to identify rival amici. From these readings several things became clear. First, attorneys generally spell out, in the first few paragraphs of the brief, how they will consistently refer to opposition briefs. Second, amici almost wholly use the terms "amicus" and "amici" when referring to opposing amici. However, not all do so. Accordingly, we ran searches in the briefs for the terms "amicus," "amici," "friend of the court," "brief," as well as the abbreviated "br." and "brf." Once one of these terms was found, we then proceeded to read the text surrounding the searched term to determine whether the brief

29. While we are unaware of studies on the Supreme Court that analyze conflict in briefs in relation to the Court's dispositions, Walter's (1988) seminal study on summation in jury trials indicates that the ability to address points made by one's opponent influences jury decision making.

30. Note that, due to the expedited briefing in Felker $v$. Turpin, which required that all briefs be due the same day, this case is excluded from the analysis as the respondent amici did not have the opportunity to read the petitioner amici's briefs. 
was indeed making reference to one of the opposing (petitioner) amicus briefs for the purposes of invalidating the argumentation in that brief. The amicus brief of the State of Louisiana in Meghrig v. KFC Western (1996) offers one of the more typical examples of citations to an opposition brief. This brief is coded as having cited the amicus brief of Western State Petroleum Association, as it states the following:

the Western States Petroleum Association as Amicus Curiae, argue that recovery of remediation expenditures under RCRA [Resource Conservation and Recovery Act] is improper because permitting such relief would nullify CERCLA's [Comprehensive Environmental Response, Compensation, and Liability Act] petroleum exclusion.... This argument is without merit. ${ }^{31}$

Table 5 reports the results of our measure of conflict. Respondent amici (and the respondent party) are listed across the top of the table, while petitioner amici are listed in the left-hand column. ${ }^{32}$ The first entry in the column indicates the percentage of times the respondent amicus (individuals) cited an amicus brief filed by the petitioner amicus (individuals), relative to the sixteen briefs in which opposing individuals appeared on briefs supporting the petitioner and respondent (which constitutes the numbers in parentheses). Therefore, this percentage reveals that, of the sixteen briefs in which competing individuals supported both the petitioner and respondent, the individual respondent amici cited the individual petitioner amici once.

Four salient points can be derived from Table 5. First, while there is a great deal of competition among the amici (as reported in Tables 1 and 4), actual conflict between the amici is somewhat rare. Specifically, of all of the opportunities to engage in direct discord with an opponent amici, respondent amici only cited petitioner amici 15 percent of the time. Indeed, if we utilize the petitioner-respondent brief-dyad as the unit of analysis (as opposed to the petitioner-respondent group type-dyad), we get the same result: citations are made to petitioner briefs in only 15 percent of cases.

Second, while the overall levels of conflict between the amici are low, direct citations to petitioner amicus briefs by the respondent party are a relatively common phenomenon. Overall, the respondent parties cited petitioner amicus briefs almost 30 percent of the time. This is a fascinating result as it provides evidence for our contention that amici supporting the petitioner alter the informational environment at the Court by changing

31. See amicus curiae brief of the State of Louisiana, Meghrig v. KFC Western (1996).

32. In the data from which Table 5 is derived, each group type who appeared on an amicus brief supporting the petitioner is tied to each group type who appeared on an amicus brief supporting the respondent. As such, this table differs from Table 4, in which the data were derived from the cases in which each category of amici participated: here the data are based on the briefs in which each category of amicus participated. 
TABLE 5.

Conflict Among Amici Curiae of a Given Type

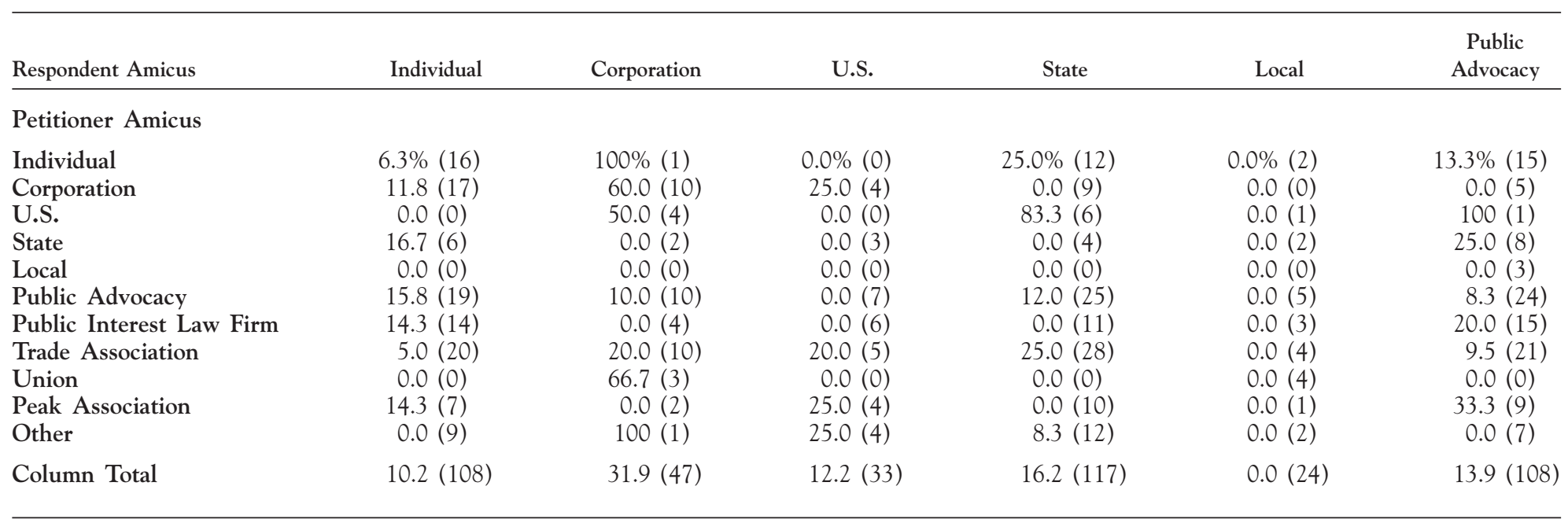




\section{TABLE 5. Continued}

\begin{tabular}{|c|c|c|c|c|c|c|c|}
\hline Respondent Amicus & $\begin{array}{c}\text { Public Interest } \\
\text { Law Firm }\end{array}$ & $\begin{array}{c}\text { Trade } \\
\text { Association }\end{array}$ & Union & $\begin{array}{c}\text { Peak } \\
\text { Association }\end{array}$ & Other & $\begin{array}{l}\text { Respondent } \\
\text { Party }\end{array}$ & Row Totals \\
\hline \multicolumn{8}{|l|}{ Petitioner Amicus } \\
\hline Individual & $33.3 \%(3)$ & $0.0 \%(6)$ & $0.0 \%(0)$ & $0.0 \%(6)$ & $20.0 \%(10)$ & $15.3 \%(13)$ & $14.3 \%(84)$ \\
\hline Corporation & $0.0(11)$ & $6.5(62)$ & $0.0(0)$ & $0.0(7)$ & $0.0(3)$ & $20.0(25)$ & $11.7(153)$ \\
\hline U.S. & $0.0(1)$ & $84.6(13)$ & $83.3(6)$ & $50.0(6)$ & $0.0(0)$ & $92.9(14)$ & $76.9(52)$ \\
\hline State & $0.0(7)$ & $6.7(15)$ & $0.0(0)$ & $0.0(6)$ & $0.0(4)$ & $38.5(13)$ & $12.9(70)$ \\
\hline Local & $0.0(3)$ & $0.0(2)$ & $0.0(0)$ & $0.0(6)$ & $0.0(0)$ & $0.0(8)$ & $0.0(22)$ \\
\hline Public Advocacy & $0.0(23)$ & $3.7(54)$ & $0.0(1)$ & $3.3(30)$ & $0.0(14)$ & $26.0(50)$ & $9.5(262)$ \\
\hline Public Interest Law Firm & $0.0(12)$ & $0.0(38)$ & $0.0(1)$ & $0.0(16)$ & $0.0(9)$ & $12.9(31)$ & $5.6(160)$ \\
\hline Trade Association & $21.1(19)$ & $11.3(79)$ & $25.0(4)$ & $5.6(18)$ & $12.5(8)$ & $28.7(73)$ & $17.3(289)$ \\
\hline Union & $0.0(0)$ & $0.0(8)$ & $0.0(4)$ & $0.0(3)$ & $0.0(0)$ & $66.6(3)$ & $16.0(25)$ \\
\hline Peak Association & $16.7(6)$ & $17.6(17)$ & $0.0(1)$ & $0.0(6)$ & $0.0(4)$ & $47.6(21)$ & $21.6(88)$ \\
\hline Other & $10.0(10)$ & $0.0(19)$ & $0.0(0)$ & $0.0(12)$ & $37.5(8)$ & $4.8(12)$ & $8.3(96)$ \\
\hline Column Total & $7.4(95)$ & $9.6(313)$ & $35.2(17)$ & $4.3(116)$ & $10.0(6)$ & $28.9(263)$ & $14.9(1,301)$ \\
\hline
\end{tabular}

Entries represent the percentage of briefs in which the respondent amicus (or party) directly cited an amicus brief on which the petitioner amici appeared. Numbers in parentheses indicate number of briefs on which both the petitioner and respondent amicus (or party) appeared. 
the nature of the argumentation in respondent party briefs. In particular, instead of focusing solely on refuting the positions espoused by the petitioning party and defending the lower court's disposition of the case, respondents regularly attack petitioner amici for the purposes of weakening and/or refuting the points of law and policy advocated by those organized interests. As such, these results provide novel insight into the important role amicus participants play in directing the flow of information at the Court.

Third, of all the petitioning amici, the most common organized interest under attack is the Solicitor General (SG): of the fifty-two opportunities to engage in direct discord with the SG, respondents and respondent amici did so more than 75 percent of the time. This provides substantial evidence that the amici and the parties give especially singular attention to the SG, no doubt in an endeavor to diminish the office's high success rates at the merits stage (e.g., O'Connor 1983; Segal 1988). By engaging in this type of direct conflict with the federal government, amici attempt to level the playing field by focusing the justices' attention on their attempts to neutralize persuasion attempts made by SGs. Interestingly, SGs rarely involve themselves in such attacks, citing petitioner amicus briefs only 12 percent of time. Instead, SGs focus their briefs on developing their own points of law and policy.

Finally, of the remaining amici, trade associations, peak associations, and unions are most commonly attacked, while public interest law firms, public advocacy organizations, states, and corporations remain relatively unscathed. As such, it does not appear that either institutional or membership-based groups are especially susceptible to assailment by petitioner amici. This reinforces the point that, while there is a great deal of competition among interest groups in the Court (i.e., many opportunities for conflict), there is little evidence of direct discord between the amici.

\section{CONCLUSIONS}

This analysis has examined organized interest participation, competition, and conflict in the U.S. Supreme Court. Our findings with regard to the participation of amici curiae reveal that the Supreme Court is remarkably accessible to a wide array of interest groups. As such, we provide confirmation that, despite research that questions the very feasibility of pluralism (e.g., Browne 1990), evidence does exist of a pluralistic society, at least in terms of interests participating as amici in the Supreme Court. That is, corporations and institutions do not dominate the interest group choir in the Court; instead, a host of membership-based organizations play their part in the Court's jurisprudence. Our findings relating to competition and conflict among organized interests are of particular interest. While we uncover that there is a great deal of competition among interest groups in the Court, we find little evidence of direct conflict, with citations to opponent briefs for 
the purposes of refuting their argumentation occurring in less than 15 percent of opportunities to do so. Nonetheless, when interest groups engage in this type of conflict, they play a clear role in shaping the information environment at the Court. As such, our analysis of conflict contributes to the literature that investigates the types of information provided organized interest in the judicial arena (e.g., Comparato 2003; Parker 1999; Spriggs and Wahlbeck 1997).

While we have provided a comprehensive analysis of interest group activity in the Supreme Court, we encourage future researchers to investigate a number of related but unexplored aspects of organized involvement in the judicial system that touch on both normative and empirical concerns. For example, despite the fact our results indicate that a wide variety of interests participate in Supreme Court litigation, our conclusions are limited in that we are unable to categorically state that disadvantaged groups are able to utilize the courts as an outlet for social change. To do this, researchers might employ an alternative strategy for the classification of groups, examine the types of litigants the amici support, analyze the positions amici espouse, or explore the resources at the disposal of each amici. This is clearly a productive line of inquiry that will surely contribute to our knowledge of possible biases in the administration of justice. Similarly, because our analysis is focused on a single term of a single court, we invite others to analyze the applicability of this research to other terms and other courts. Indeed, it is only through multiterm analyses that future researchers will be able to identify the groups that forge long-term alliances with each other in their attempts to influence the courts; in addition, this strategy will provide the opportunity to distinguish the groups these amici regularly oppose. As it is now clear that group participation in the Court is marked by substantial coalition formation and competition, this research will surely benefit our understanding of the strategies and effectiveness of groups in the judicial branch. Likewise, applying this research design to lower courts has the promise of offering leverage over whether biases exist with regard to pressure group participation in those courts. With the Supreme Court's shrinking workload, the courts of appeals have become the de facto courts of last resort in the American legal system (Hettinger, Lindquist, and Martinek 2006, 13). Yet, despite the significant role these courts play, little is known about the types of groups participating in these courts, or the levels of competition and conflict between the amici. Finally, and perhaps most importantly, future research should focus on how amici affect the choices jurists make. While there is a substantial literature that examines the influence of amici on litigation success, little research has focused on the role of organized interests in shaping policy and doctrinal change in the courts. Further, scholars have given scant attention as to whether certain types of organizations are more effective than others in their attempts to influence judicial decision making. Although we have provided evidence that a wide array of pressure groups participate in the Supreme Court, our results cannot speak to whether certain types of amici are especially 
influential. In other words, a pluralist portrait of group participation in the Court is not necessarily indicative of pluralist influence on the Court. Additional research into these, and other unexplored areas of interest group involvement in the judiciary, will undoubtedly increase our understanding of the important role organized interests play in the judicial arena.

\section{REFERENCES}

Basinger, Nancy Winemiller. 2004. The Legal Strategy Choices of Charities in Their Court-Based Advocacy Efforts. Paper presented at the Annual Meeting of the Midwest Political Science Association, Chicago, April 15-18.

Behuniak-Long, Susan. 1991. Friendly Fire: Amici Curiae and Webster v. Reproductive Health Services. Judicature 74:261-70.

Bentley, Arthur F. 1908. The Process of Government. Chicago: University of Chicago Press.

Berry, Jeffrey M. 1997. The Interest Group Society, 3rd ed. New York: Longman.

Bradley, Robert C., and Paul Gardner. 1985. Underdogs, Upperdogs, and the Use of the Amicus Curiae Brief. Justice System Journal 19:78-96.

Browne, William P. 1990. Organized Interests and Their Issue Niches: A Search for Pluralism in a Policy Domain. Journal of Politics. 52:477-509.

Caldeira, Gregory A., Marie Hojnacki, and John R. Wright. 2000. The Lobbying Activities of Organized Interests in Federal Judicial Nominations. Journal of Politics 62:51-69.

Caldeira, Gregory A., and John R. Wright. 1988. Organized Interests and Agenda Setting in the U.S. Supreme Court. American Political Science Review 82:1109-27.

1990. Amici Curiae Before the Supreme Court: Who Participates, When, and How Much. Journal of Politics 52:782-806.

Collins, Paul M., Jr. 2004. Friends of the Court: Examining the Influence of Amicus Curiae Participation in U.S. Supreme Court Litigation. Law Eु Society Review 38:80732.

2007. Lobbyists before the U.S. Supreme Court: Investigating the Influence of Amicus Curiae Briefs. Political Research Quarterly 60:55-70.

Comparato, Scott A. 2003. Amici Curiae and Strategic Behavior in State Supreme Courts. Westport, CT: Praeger.

Cortner, Richard C. 1968. Strategies and Tactics of Litigants in Constitutional Cases. Journal of Public Law 17:287-307.

Dahl, Robert A. 1961. Who Governs? Democracy and Power in an American City. New Haven, CT: Yale University Press.

Day, Jack G. 2001. Words that Counted—A Vignette. Case Western Reserve Law Review 52:373-74.

Ennis, Bruce L. 1984. Effective Amicus Briefs. Catholic University Law Review 33:603-09.

Epstein, Lee. 1985. Conservatives in Court. Knoxville: The University of Tennessee Press.

—. 1991. Courts and Interest Groups. In The American Courts: A Critical Assessment, ed. John B. Gates and Charles A. Johnson. Washington, DC: Congressional Quarterly Press.

1994. Exploring the Participation of Organized Interests in State Court Litigation. Political Research Quarterly 47:335-51.

Epstein, Lee, and Gary King. 2002. The Rules of Inference. University of Chicago Law Review 69:1-133.

Gibson, James L. 1997. United States Supreme Court Judicial Data Base, Phase II: 19531993. Ann Arbor, MI: Inter-University Consortium for Political and Social Research. 


\section{LAW \& SOCIAL INQUIRY}

Hettinger, Virginia A., Stefanie A. Lindquist, and Wendy L. Martinek. 2006. Judging on a Collegial Court: Influences on Federal Appellate Decision Making. Charlottesville: University of Virginia Press.

Ivers, Gregg, and Karen O'Connor. 1987. Friends as Foes: The Amicus Curiae Participation and Effectiveness of the American Civil Liberties Union and Americans for Effective Law Enforcement in Criminal Cases, 1969-1982. Law $\mathcal{E}$ Policy 9:161-78.

Jost, Kenneth. 1996. The Supreme Court Yearbook, 1995-1996. Washington, DC: Congressional Quarterly Press.

Kearney, Joseph D., and Thomas W. Merrill. 2000. The Influence of Amicus Curiae Briefs on the Supreme Court. University of Pennsylvania Law Review 148:743-855.

Kearney, Richard C., and Reginald S. Sheehan. 1992. Supreme Court Decision Making: The Impact of Court Composition on State and Local Government Litigation. Journal of Politics 54:1008-25.

King, Gary, Robert O. Keohane, and Sidney Verba. 1996. Designing Social Inquiry. Princeton, NJ: Princeton University Press.

Kolbert, Kathryn. 1989. The Webster Amicus Curiae Briefs: Perspectives on the Abortion Controversy and the Role of the Supreme Court. American Journal of Law $\mathcal{E}$ Medicine 15:153-69.

Krislov, Samuel. 1963. The Amicus Curiae Brief: From Friendship to Advocacy. Yale Law Journal 72:694-721.

Kuersten, A.K., and Jason Jagemann. 2000. Does the Interest Group Choir Really "Sing with an Upper Class Accent?" Coalitions of Race and Gender Groups Before the Supreme Court. Women Eु Politics 21:53-73.

Lowman, Michael K. 1992. The Litigating Amicus Curiae: When Does the Party Begin After the Friends Leave? American University Law Review 41:1243-99.

Lynch, Kelly J. 2004. Best Friends?: Supreme Court Law Clerks on Effective Amicus Curiae Briefs. Journal of Law $\mathcal{B}$ Politics 20:33-75.

McGuire, Kevin T. 1990. Obscenity, Libertarian Values and Decision Making in the Supreme Court. American Politics Quarterly 18:47-67.

. 1995. Repeat Players in the Supreme Court: The Role of Experienced Lawyers in Litigation Success. Journal of Politics 57:187-96.

Morris, Thomas R. 1987. States Before the U.S. Supreme Court: State Attorneys General as Amicus Curiae. Judicature 70:298-305.

O'Connor, Karen. 1983. The Amicus Curiae Role of the U.S. Solicitor General in Supreme Court Litigation. Judicature 66:256-64.

O'Connor, Karen, and Lee Epstein. 1982. The Importance of Interest Group Involvement in Employment Discrimination Litigation. Howard Law Journal 25:709-29.

—. 1983a. Court Rules and Workload: A Case Study of Rules Governing Amicus Curiae Participation. Justice System Journal 8:35-45.

— 1983b. The Rise of Conservative Interest Group Litigation. Journal of Politics 45:479-89.

—. 1989. Public Interest Law Groups. Westport, CT: Greenwood Press.

Parker, Frederick R. 1999. Washington v. Glucksberg and Vacco v. Quill: An Analysis of the Amicus Curiae Briefs and the Supreme Court's Majority and Concurring Opinions. Saint Louis University Law Journal 43:469-542.

Perry, H. W., Jr. 1991. Deciding to Decide: Agenda Setting in the United States Supreme Court. Cambridge, MA: Harvard University Press.

Puro, Steven. 1971. The Role of Amicus Curiae in the United States Supreme Court: 1920-1966. PhD diss., Department of Political Science, State University of New York at Buffalo, Buffalo, NY.

Rustad, Michael, and Thomas Koenig. 1993. The Supreme Court and Junk Social Science: Selective Distortion in Amicus Briefs. North Carolina Law Review 72:91-162. 
Salisbury, Robert H. 1984. Interest Representation: The Dominance of Institutions. American Political Science Review 78:64-76.

Salisbury, Robert H., John P. Heinz, Edward O. Laumann, and Robert L. Nelson. 1987. Who Works With Whom? Interest Group Alliance and Opposition. American Political Science Review 81:1217-34.

Samuels, Suzanne U. 2004. First Among Friends: Interest Groups, the U.S. Supreme Court, and the Right to Privacy. Westport, CT: Praeger.

Schattschneider, E. E. 1960. The Semisovereign People: A Realist's View of Democracy in America. New York: Holt, Rinehart, and Winston.

Scheppele, Kim Lane, and Jack L. Walker, Jr. 1991. The Litigation Strategies of Interest Groups. In Mobilizing Interest Groups in America: Patrons, Professions, and Social Movements, ed. Jack L. Walker, Jr. Ann Arbor: University of Michigan Press.

Schlozman, Kay L. 1984. What Accent the Heavenly Chorus? Political Equality and the American Pressure System. Journal of Politics 46:1006-32.

Schlozman, Kay L., and John T. Tierney. 1986. Organized Interests and American Democracy. New York: Harper and Row.

Segal, Jeffrey A. 1988. Amicus Curiae Briefs by the Solicitor General During the Warren and Burger Courts. Western Political Quarterly 41:135-44.

Songer, Donald R., and Reginald S. Sheehan. 1993. Interest Group Success in the Courts: Amicus Participation in the Supreme Court. Political Research Quarterly 46:339-54.

Spaeth, Harold J. 2004. The Original United States Supreme Court Database, 1953-2004 Terms. East Lansing: Department of Political Science, Michigan State University.

Spriggs, James F., and Paul J. Wahlbeck. 1997. Amicus Curiae and the Role of Information at the Supreme Court. Political Research Quarterly 50:365-86.

Sungaila, Mary-Christine. 1999. Effective Amicus Practice Before the United States Supreme Court: A Case Study. Southern California Review of Law and Women's Studies 8:187-96.

Truman, David B. 1951. The Governmental Process: Political Interests and Public Opinion. New York: Knopf.

Vose, Clement. 1955. NAACP Strategy in the Covenant Cases. Western Reserve Law Review 6:101-45.

Walker, Jack L., JR. 1991. Mobilizing Interest Groups in America: Patrons, Professions, and Social Movements. Ann Arbor: University of Michigan Press.

Walter, Bettyruth. 1988. The Jury Summation As Speech Genre: An Ethnographic Study of What it Means to Those Who Use It. Amsterdam: J. Benjamins Publishing Co.

Wasby, Stephen L. 1995. Race Relations Litigation in an Age of Complexity. Charlottesville: University Press of Virginia.

Wohl, Alexander. 1996. Friends with Agendas: Amicus Curiae Briefs May Be More Popular Than Persuasive. American Bar Association Journal 82:46-50.

Wright, John R. 1989. PAC Contributions, Lobbying, and Representation. Journal of Politics 51:713-29.

\section{CASES CITED}

BMW of North America v. Gore, 517 U.S. 559 (1996).

Brown v. Board of Education, 347 U.S. 483 (1954).

Colorado Republican Federal Campaign Committee v. FEC, 518 U.S. 604 (1996).

Cooper v. Oklahoma, 517 U.S. 348 (1996).

Doctor's Associates v. Casarotto, 517 U.S. 681 (1996).

Ex Parte McCardle, 74 U.S. 506 (1868). 


\section{LAW \& SOCIAL INQUIRY}

Exxon v. Sofec, 517 U.S. 830 (1996).

Felker v. Turpin, 518 U.S. 651 (1996).

Lewis v. Casey, 518 U.S. 343 (1996).

Lotus Development v. Borland International, 516 U.S. 233 (1996).

Loving v. United States, 517 U.S. 748 (1996).

Mapp v. Ohio, 367 U.S. 643 (1961).

Medtronic v. Lohr, 518 U.S. 470 (1996).

Meghrig v. KFC Western, 516 U.S. 479 (1996).

Shaw v. Hunt, 517 U.S. 899 (1996).

Whren v. United States, 517 U.S. 806 (1996). 